\title{
Percutaneous pulmonary valve implant: two Colombian case reports
}

\author{
Implante percutáneo de válvula pulmonar: a propósito de dos casos colombianos
}

Luis H. Díaz, Rafael Lince, Keerby Hernández,, Rafael Correa, and Arnaldo Palomino

Department of Pediatric Cardiology, Clínica CardioVID. Medellin, Colombia

\begin{abstract}
Patients with congenital heart disease that involves reconstruction of the right ventricular (RV) outflow tract must frequently undergo interventions derived from the limited useful life of the surgical canals, which leads to the development of RV dysfunction due to changes in the ventricular geometry and predisposition to lethal arrhythmias, with the consequent risk of reinterventions. The percutaneous pulmonary valvular implant is a new therapeutic alternative, less invasive, compared to surgery, for selected patients. A review of the available literature is made, and the initial experience of percutaneous pulmonary valve implantation in a Colombian center of high complexity for the treatment of cardiovascular diseases is described, in two patients with aortic homograft dysfunction in a pulmonary position with double valvular lesion, in which the percutaneous pulmonary valve implant was a successful strategy. Patients with congenital heart disease were chosen, with dysfunctional surgical conduits with stenosis or significant pulmonary insufficiency, with dysfunction and RV dilatation. The standard technique for the implantation of the Melody pulmonary valve was used without complications during the procedure or 1 year of follow-up. Percutaneous implantation of the pulmonary valve is a great advance in the management of patients with congenital heart diseases, with favorable results in the short and medium-term, allowing the restoration of ventricular function with minimal risk, compared to surgical replacement in selected patients.
\end{abstract}

Key words: Pulmonary valve stenosis. Pulmonary valve insufficiency. Prostheses and implants. Endovascular procedures. Congenital heart disease.

\section{Resumen}

Los pacientes con cardiopatías congénitas que afectan la continuidad del ventrículo derecho con la arteria pulmonar deben someterse con frecuencia a intervenciones debido a la limitada vida útil de los conductos quirúrgicos, lo que lleva al desarrollo de disfunción ventricular derecha por cambios en la geometría ventricular y predisposición a arritmias letales, con el consiguiente riesgo de reintervenciones. El implante valvular percutáneo pulmonar es una nueva alternativa terapéutica, menos invasiva en comparación con la quirúrgica, para pacientes seleccionados. Se realiza una revisión de las publicaciones médicas actuales disponibles y se describe la experiencia inicial del implante valvular pulmonar percutáneo en un centro colombiano de alta complejidad para el tratamiento de enfermedades cardiovasculares, en dos pacientes con disfunción del homoinjerto aórtico en posición pulmonar con doble lesión valvular, en los cuales el implante valvular pulmonar percutáneo fue una conducta exitosa. Se eligió a pacientes con cardiopatías congénitas, conductos quirúrgicos disfuncionales con

\section{Correspondence:}

*Keerby Hernández

E-mail: keerby.cardioped@gmail.com
Date of reception: 13-06-2019

Date of acceptance: 10-01-2020

DOI: 10.24875/ACME.M20000131
Available online: 04-12-2020 Arch Cardiol Mex (Eng). 2020;90(3):286-293 www.archivoscardiologia.com 2604-7063 / C 2020 Instituto Nacional de Cardiología Ignacio Chávez. Published by Permanyer. This is an open access article under the CC BY-NC-ND license (http://creativecommons.org/licenses/by-nc-nd/4.0/). 
estenosis o insuficiencia pulmonar significativa, y disfunción y dilatación ventricular derechas. Se empleó la técnica regular para el implante de la válvula pulmonar Melody, sin documentarse complicaciones durante el procedimiento ni al año de seguimiento. El implante percutáneo de la válvula pulmonar es un gran avance en el tratamiento de pacientes con cardiopatías congénitas, con resultados favorables a corto y mediano plazos, lo cual hace posible la restauración de la función ventricular con riesgo mínimo, frente al reemplazo quirúrgico en pacientes seleccionados.

Palabras clave: Estenosis de la válvula pulmonar. Insuficiencia de la válvula pulmonar. Prótesis e implantes. Procedimientos endovasculares. Cardiopatías congénitas.

\section{Introduction}

Current treatment of congenital heart disease, along with the advances in non-invasive imaging techniques, the development of new surgical procedures, and hemodynamic interventionism, has contributed to an increase in patient survival, but also to the need for more reoperations ${ }^{1}$. For that reason, it is important to apply new techniques that reduce morbidity and mortality and favor longer periods free of interventions.

Surgical techniques that include continuity between the right ventricle and the pulmonary artery are often associated with right ventricular (RV) outflow tract dysfunction in the late post-operative period ${ }^{2}$. This physiological alteration, added to pulmonary valve chronic dysfunction, can cause deleterious effects to the RV function, dilatation, and predisposition to life-threatening arrhythmias, with a negative effect on the quality of life, symptom progression, and decreased exercise capacity ${ }^{3}$. The early intervention aimed at restoring pulmonary valve function can prevent and even reverse this process.

Percutaneous pulmonary valve implantation is a less invasive alternative than surgery for valve replacement, which can be used in selected patients ${ }^{4}$. From its description in the year 2000 to date, different world centers adopted this practice, with more than 10,000 percutaneous valves implanted all over the world ${ }^{5}$. Short- and mid-term results show a high rate of successful procedures with adequate pulmonary valve function ${ }^{6}$ and low reoperation rates with improvements in functional class (NYHA) and hemodynamic parameters ${ }^{7,8}$. The main causes of dysfunction are related to stenosis due to early elastic constriction (recoil) and loss of radial force due to stent fracture ${ }^{9,10}$.

Numerous studies show that RV outflow tract dysfunction resolution through percutaneous pulmonary valve implantation corrects the RV remodeling processes and the degree of tricuspid regurgitation, in addition to improving biventricular function ${ }^{6,11,12}$.

The purpose of this description of clinical cases is to show the experience, in a Colombian center specialized in the treatment of cardiovascular diseases, on percutaneous pulmonary valve implantation in two patients with congenital heart disease initially corrected with aortic homografts in pulmonary position, and who subsequently developed pulmonary valve double lesions (stenosis and insufficiency).

\section{Case 1}

A 16-year-old male patient of $50 \mathrm{~kg}$ of weight, with a history of RV double outflow tract, pulmonary stenosis, abdominal-atrial situs inversus, and dextrocardia, initially underwent a Kawashima-Rastelli operation at age three with a 19-mm-diameter aortic valve graft in pulmonary position. During outpatient follow-up, progressive NYHA functional Class II deterioration was identified, with the development of graft dysfunction 13 years after the implantation, as well as a double lesion: progressive pulmonary stenosis and moderate pulmonary insufficiency. During the last control, an echocardiogram revealed a homograft with severe stenosis, $77-\mathrm{mmHg}$ maximum gradient and mean of $47 \mathrm{mmHg}$, and moderate insufficiency. In addition, RV mild dilation and hypertrophy were observed. With these findings, a magnetic resonance imaging scan of the heart was requested. A dilated right ventricle was revealed, with outflow tract aneurysm and a diastolic diameter of $55 \mathrm{~mm}, 27 \%$ regurgitant fraction, end-diastolic volume of $152 \mathrm{~cm}^{3} / \mathrm{m}^{2}$, end-systolic volume of $49 \mathrm{~cm}^{3} / \mathrm{m}^{2}$, and ejection fraction of $63 \%$; a dilated left ventricle (LV) was also observed, with an end-diastolic of volume $84 \mathrm{~cm}^{3} / \mathrm{m}^{2}$ and an ejection fraction of $60 \%$ without contractility segmental alterations.

After considering the functional class deterioration and the findings in the studies, the patient was eligible for percutaneous pulmonary valve implantation. The percutaneous valve implantation procedure (see description below) was performed at the hemodynamic laboratory under general anesthesia, orotracheal intubation, and cardiovascular anesthesia care; selective coronary angiographies were obtained before the implantation to assess in detail the coronary anatomy, as shown in figure 1. There were no complications during 


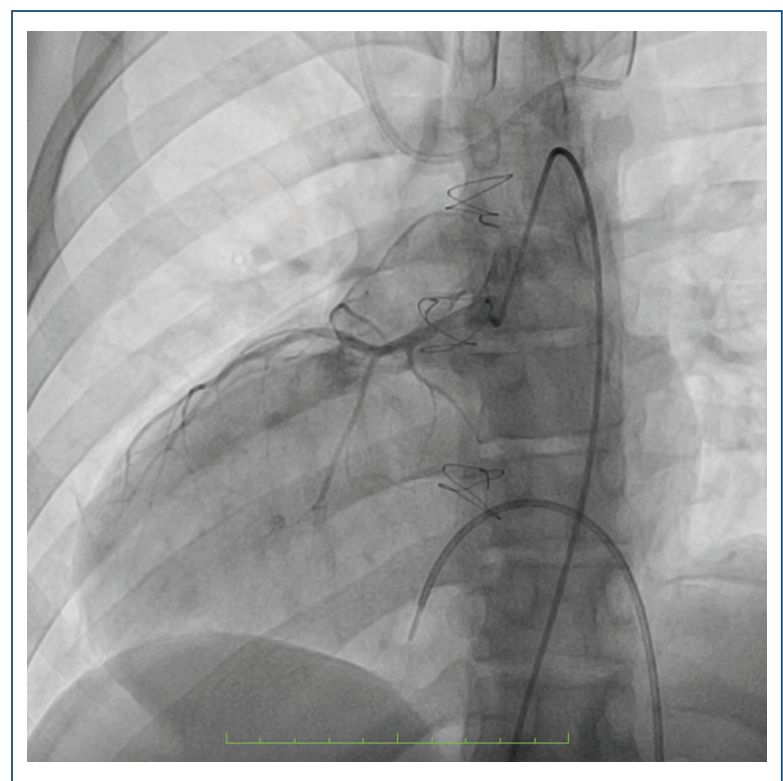

Figure 1. Fluoroscopic image before pulmonary valve implantation: coronary arteries with normal origin and trajectory are observed, without anatomical defects representing a risk for occlusion.

the procedure. Subsequently, the patient was admitted to the pediatric intensive care unit for 1 day without the need for hemodynamic or ventilatory support. An echocardiogram the next day after the valve implantation showed the homograft in pulmonary position, stent in adequate position, permeable Melody valve, and good mobility with a maximum gradient of $25 \mathrm{mmHg}$ and mean of $13 \mathrm{mmHg}$, without pulmonary valve insufficiency. He was discharged the hospitalization $2^{\text {nd }}$ day.

\section{Case 2}

Patient aged 18 years, weighing $50 \mathrm{~kg}$, with a history of tetralogy of Fallot-type congenital heart disease, which required a Blalock-Taussig fistula in the neonatal period and then a Rastelli operation. A 20-mm-diameter homograft was implanted in the pulmonary position, and the following year, homograft stenosis was identified, which required pulmonary angioplasty, with good hemodynamic results. Continued outpatient follow-up was provided, in which, during his evolution, the patient developed a double lesion consisting of moderate pulmonary stenosis and free regurgitation, for which complementary studies were requested to assess for hemodynamic implications and to define a cardiovascular plan. The echocardiogram identified moderate stenosis of the homograft in pulmonary position, with a maximum gradient of $85 \mathrm{mmHg}$ and a mean $56 \mathrm{mmHg}$, free pulmonary regurgitation, and RV dilation. Heart MRI outlined a dilated right ventricle with diffuse hypokinesia, $25 \%$ regurgitant fraction, $57 \%$ ejection fraction, end-diastolic volume of $103 \mathrm{~mL} / \mathrm{m}^{2}$, and end-systolic volume of $35 \mathrm{~mL} / \mathrm{m}^{2}$. The LV showed a normal size, without hypertrophy or contractility alterations, ejection fraction of $61 \%$, end-diastolic volume of $64 \mathrm{~mL} / \mathrm{m}^{2}$, and end-systolic volume $25 \mathrm{~mL} / \mathrm{m}^{2}$, with $25 \%$ regurgitation fraction.

The case was analyzed in a medical-surgical discussion, and based on cardiac imaging findings, the patient was considered suitable for Melody valve percutaneous implantation. The procedure was carried out under the same conditions as the previous case, and no complications were documented during its performance. Intracardiac echocardiogram did not reveal paravalvular leak or pulmonary regurgitation. The patient was moved to the intensive care unit, where he remained for 1 day for hemodynamic surveillance, where he had a favorable clinical course, without heart rate disturbances or hypoperfusion episodes. Subsequently, he was transferred to the hospitalization ward and discharged on the $2^{\text {nd }}$ day of hospital stay.

\section{Description of procedure's technique}

Right and left cardiac catheterization is performed, with percutaneous femoral access. A wedge catheter is used to measure right circulation pressures, and a helical catheter is employed for RV angiography. Exchange is made using a $0.35 \times 260-\mathrm{cm}$ Lunderquist guidewire and, over it, an Atlas balloon is advanced, which expands within the RV outflow tract, with simultaneous selective coronary angiography to rule out extrinsic compression (Fig. 2). The outflow tract and homograft are prepared with implantation of a covered Cheatham Platinum (CP) stent over a Numed balloon in balloon (BIB), as shown in figure 3 . Then, the Melody valve is prepared (in one of the cases after attaching an additional Andra XL stent onto this prosthesis) and advanced with the ENSAMBLE system to the landing zone created with the covered CP stent. The internal balloon is inflated, adequate position is verified (Fig. 4), and then the external balloon is inflated to satisfactorily impact on the valve. Control angiograms of the pulmonary artery and right ventricle are obtained (Fig. 4), and control coronary angiograms are repeated to rule out compression. The main results obtained in the hemodynamics laboratory are presented in Table 1 and for each one of the reported patients. 


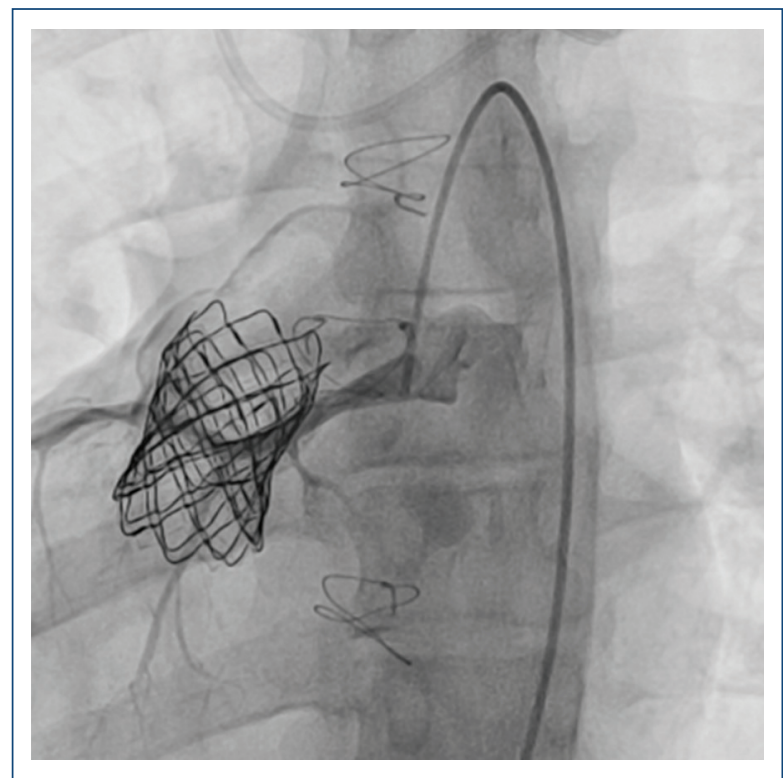

Figure 2. Fluoroscopic image obtained after percutaneous valve implantation. No extrinsic compression was demonstrated.

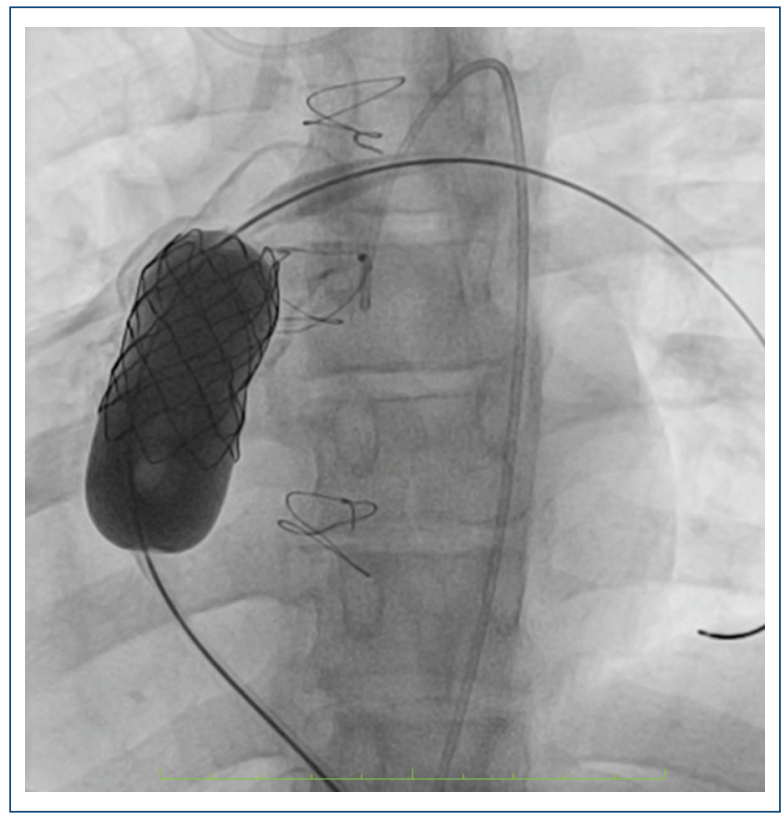

Figure 3. Right ventricular outflow tract angiography. Implantation of a covered cheatham platinum stent onto a Numed (balloon in balloon) balloon in the right ventricle outflow tract over the aortic homograft in lung position.

Outpatient follow-up of both patients was carried out 1 month after the procedure with echocardiogram and electrocardiogram, and then at 6 months and

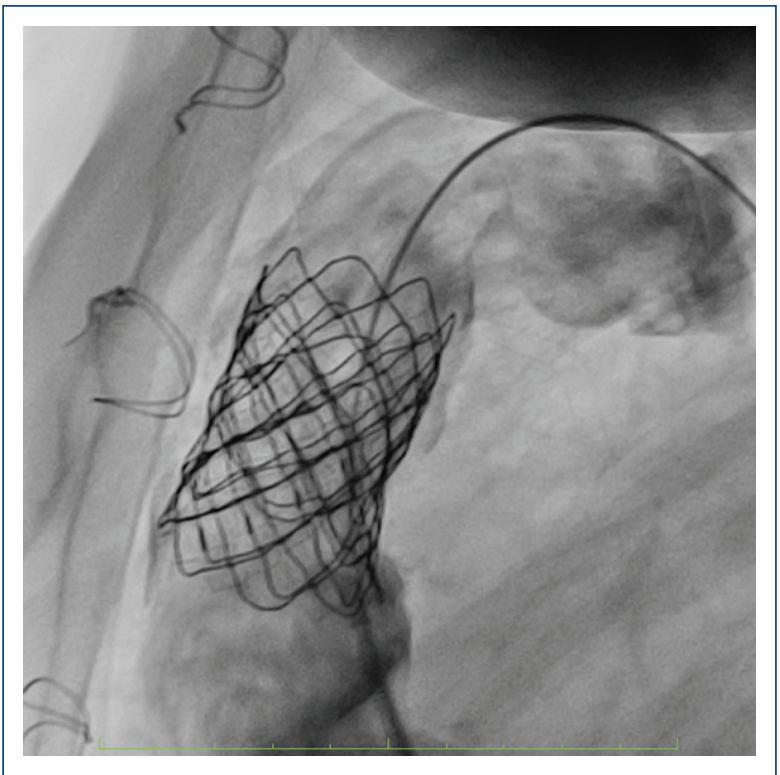

Figure 4. Implanted Melody valve image. Right ventricle outflow tract angiography. Implanted valve adequate position verification.

1 year after the procedure. None of them required reoperation. There were no changes in heart rate. One of the patients with NYHA functional Class II at the time of implantation reported improvement in tolerance to exercise 1 month after the intervention. Both patients received anti-platelet aggregation therapy with acetylsalicylic acid during the first 6 months following the procedure. The outpatient echocardiographic evaluation showed a significant improvement in pulmonary volumes and right ventricle functional evaluation measured by TAPSE. No residual pulmonary regurgitation or fracture of the Melody valve was observed. No late complications related to the percutaneous implant were recorded at 1 year of follow-up.

\section{Discussion}

Surgical procedures for congenital heart diseases that compromise the RV outflow tract and pulmonary artery often involve the implantation of a duct to restore the connection between the right ventricle and the pulmonary artery. In pediatric patients, these ducts frequently must be replaced and show a limited useful life that varies depending on patient age and the material used ${ }^{13}$ due to somatic growth and degeneration of the duct, which can cause stenosis or insufficiency. This represents a ventricular remodeling with subsequent 
Table 1. Hemodynamic values

\begin{tabular}{|l|c|c|c|c|}
\hline \multicolumn{5}{|c|}{ Hemodynamic study, case 1 } \\
\hline Cavity & SP* & DP* & DP2* & MP* \\
\hline RV* & 54 & & 10 & \\
\hline Desc. ao. & 81 & 46 & & 52 \\
\hline & Post-Melody 22 valve implantation \\
\hline PA* $^{*}$ & 34 & 16 & & 23 \\
\hline RV* & 35 & 0 & 10 & \\
\hline Desc. ao.* & 100 & 65 & & 61 \\
\hline Catheterization time, 130 min & & \\
\hline Fluoroscopy time: $23-26$ min &
\end{tabular}

Hemodynamic study, case 2

\begin{tabular}{|l|l|l|l|}
\hline RA $^{*}$ & 10 & \\
\hline RV$^{*}$ & 88 & 0 & 13 \\
\hline PA $^{*}$ & 25 & 10 \\
\hline PARB* & 25 & 8 \\
\hline PALB & 20 & 10 \\
\hline
\end{tabular}

Left wedge

Right wedge

13

RVOT*

85

$\mathrm{LV}^{*}$

90

0

8

Asc. ao.* ${ }^{*} \quad$ g5

Desc. ao.* 95 62

Post-Melody 22 valve implantation

SVC*

$\mathrm{RA}$ *

$\mathrm{RV}^{*}$

$\mathrm{PA}^{*}$

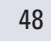

0

10

PARB*

Wedge

Intrastent 22 10

14

Aorta

110

70

84

Catheterization time: $160 \mathrm{~min}$

Fluoroscopy time: $68 \mathrm{~min}$

RV: right ventricle; Desc. ao.: descending aorta; PA: pulmonary artery; SP: systolic pressure; DP1: diastolic pressure; DP2: end-diastolic pressure; MP: mean pressure; SVC: superior vena cava; RA: right atrium; PARB: pulmonary artery right branch; PALB: pulmonary artery left branch; RVOT: right ventricular outflow tract; LV: left ventricle; Asc. ao.: ascending aorta.

dilation and deleterious consequences for RV functionality ${ }^{14}$, and this elevates inherent morbidity and the need for reoperations in periods shorter than 10 years ${ }^{15}$.
Technological advances in percutaneous interventional treatment have revolutionized the care of patients with congenital heart disease. Pulmonary valve percutaneous implantation was originally described in $2000^{16}$ and was approved by the Food and Drug Administration (FDA) as a device for human use in January 2010 to treat dysfunctional ducts in the RV outflow tract ${ }^{7}$. It is a novel and less invasive alternative than the pulmonary valve replacement surgical procedure.

At present, there are two devices approved for percutaneous pulmonary valve implantation: the Melody valve (Medtronic) is a device made of bovine jugular tissue, with a central valve of natural leaflets that open and coapt under optimal pressure conditions and is sutured onto a platinum-iridium stent that is found on a CP stent with fluoroscopic guidance and a BIB Ensemble $^{\mathrm{TM}}$ releasing system, which has an integrated sheath that protects the valve during controlled release. The system is commercially available with 18-, 20- and 22$\mathrm{mm}$ external diameters ${ }^{17}$. The Edwards SAPIEN XT valve is a valve manufactured with bovine pericardial tissue in a 14-16-mm stainless steel stent, with a sealing device that covers the proximal portion of the stent to prevent paravalvular leaks and includes the Nova Flex $^{\mathrm{TM}}$ releasing system, which stabilizes the balloon body during implantation. It is available in 23-, 26-, and $29-\mathrm{mm}$ diameters. This valve uses the releasing system that requires 22-24-Fr hydrophilic guidewires, and data on SAPIEN XT valve functionality are currently limited due to a low number of patients ${ }^{18,19}$.

The evidence on percutaneous valve implantation with Melody valve comes from analytical and descriptive multicenter studies, with large experience, especially in the US and Europe, with excellent results in the short and medium term ${ }^{8,20}$. In Latin America, its practice has been documented in interventional cardiology reference centers in Brazil and Argentina, and the technique has been observed to be feasible, safe, and effective ${ }^{2}$.

This report of two cases describes for the $1^{\text {st }}$ time the percutaneous pulmonary valve implantation experience in a high-complexity Colombian center specialized in the treatment of cardiovascular diseases and has a multidisciplinary team trained in congenital heart disease interventional treatment, with successful results in the short term.

According to current recommendations of the American Heart Association, percutaneous pulmonary valve replacement is recommended in patients with surgical ducts from the right ventricle to the pulmonary artery, with moderate-to-severe regurgitation or stenosis, which produces pressure or volume overload to the right 
ventricle, provided the patient meets the inclusion or exclusion criteria for the available valve ${ }^{21}$. In the specific case of the Melody valve, a 16- to 22-mm circumferential diameter of the homograft is also required. Both reported cases meet these requirements: they are carriers of aortic homografts in pulmonary position, of 19 and $20 \mathrm{~mm}$ in diameter, respectively, they weigh more than $30 \mathrm{~kg}$, showed moderate-to-severe double valve lesions and a regurgitation fraction higher than $25 \%$ with $\mathrm{RV}$ dilation and hypertrophy and end-diastolic volume ratios (RV/LV) higher than 1.7. In addition, during the follow-up, NYHA functional class progressive deterioration was identified in one of the cases.

The procedure was performed at the hemodynamics laboratory, with $100 \%$ oxygen under orotracheal intubation, with cardiovascular anesthesiology care, after informed consent was granted. The routes of access were the femoral venous and arterial for selective aortic angiography and coronary angiography, to detect any coronary anatomy susceptible to compression. Intravenous heparin and antibiotic prophylaxis were administered. The duct was previously dilated with balloons of progressive diameters, and selective coronary angiographies were carried out during the balloon test in the RV outflow tract in both cases, without hemodynamic, angiographic, or electrocardiographic changes suggestive of perfusion defects being recorded. The percutaneously implanted valve in both cases was a 22-mm Melody valve, over the surgical duct, released by the Ensemble system, which is designed for this purpose. The recommendations for implantation were rigorously followed. Immediate post-Melody valve implantation hemodynamic data are presented in Table 1 for each patient.

Acute perioperative complications have been described in medical publications in $6 \%$, with $2.7 \%$ of complications being life-threatening or requiring immediate intervention, such as duct rupture, perforation and obstruction of pulmonary arteries, valve displacement or lesions, and coronary arteries' compression due to LV outflow tract intervention for stent localization ${ }^{7,20}$. The latter is accompanied by high early mortality and hence the importance of knowing the coronary anatomy, which allows planning before valve implantation and avoiding unfavorable outcomes. In both presented cases, selective coronary angiographies were performed before and after the percutaneous valve implantation to assess extrinsic compression, with no complications were documented during the procedure.

The intervention was considered successful in both cases, and the implanted Melody valve had an adequate location, with a decrease in the right ventricle to pulmonary artery peak gradient and in the relationship of pressures between the right ventricle and the aorta, with mild residual pulmonary regurgitation and a gradient between the right ventricle and the pulmonary artery of $<35 \mathrm{mmHg}$ being found. In neither case was explant necessary within the $24 \mathrm{~h}$ following the procedure ${ }^{7}$.

In the short-term follow-up, the development of bacterial endocarditis has been found to be the first cause of surgical explant and mortality secondary to sepsis; the reported annual rate is $2.4 \%$ patient-year ${ }^{18}$. Most cases reveal an adequate response to antimicrobial treatment, including pathophysiological mechanisms such as alterations in the flow pattern due to residual gradient, thrombosis in situ and inadequate administration of antibiotic prophylaxis during the procedure, as well as higher bacterial adhesion in the bovine jugular venous wall for some Staphylococcus aureus strains ${ }^{22}$. In the authors' institution, the prophylactic antibiotic therapy protocol was adopted during hemodynamic intervention procedures with first-generation cephalosporins, in addition to implementation of adequate asepsis and antisepsis techniques. Endocarditis was not documented in either case.

Heart rate disorders have also been reported in medical publications, in particular de novo onset after implantation, especially ventricular extrasystoles or non-sustained ventricular tachycardia, of a transitory nature and self-limited in most cases ${ }^{23}$. In the experience of the authors, no heart rate alterations occurred.

The procedure has shown promising results in different studies, with high rates of success ${ }^{24}$. Five-year survival has been determined at $98 \%$, with an absence of reoperation in $98 \pm 1 \%$ at 3 years and $91 \pm 3 \%$ at 5 years, with shorter reoperation-free periods in patients with higher RV outflow tract obstruction gradients ${ }^{7}$. The rate of absence of transcatheter-implanted valve dysfunction in a follow-up registry at 1 year was reported to be $96.9 \%^{7}$ and $86.4 \%$ at 27 months $^{10}$. The main causes of dysfunction have been associated with recoil stenosis and stent fracture due to loss of radial force $e^{9,10}$. Factors associated with fracture include patients with severely obstructed RV outflow tracts, external compression by the chest wall when the implanted valve is directly located behind the wall, younger age at the time of intervention, and angiographic duct smaller diameter; conversely, an implant site protected by a valve bioprosthesis or previous stent has been described to be a protective factor ${ }^{10,25}$, with the latter being the case of the two described patients.

This report supports the notion that percutaneous pulmonary valve replacement is a useful interventional 
procedure in the treatment of $R V$ outflow tract obstruction and post-operative pulmonary regurgitation, which are related to deleterious effects such as RV remodeling and dysfunction, as well as progressive tricuspid valve regurgitation. By restoring pulmonary valve function with a percutaneous implant, tolerance to exercise is improved, RV volumes are reduced, and biventricular functionality is improved as LV filling is improved ${ }^{26}$, in addition to clinically relevant reductions in tricuspid regurgitation being produced, which persist even after 5 years of follow-up ${ }^{12}$.

\section{Conclusion}

Percutaneous pulmonary valve replacement is considered an attractive alternative to surgical valve replacement for restoring pulmonary function in patients with RV outflow tract dysfunction; it is safe, effective, and less invasive, with current success rates and optimistic results in the short and medium-term follow-up of selected patients, which can also be adopted by trained pediatric interventional cardiologists.

The incidence of adverse events reported in medical publications serves as a basis to reduce and, if possible, treat risk factors related to inadequate outcomes. A prolonged follow-up is needed to assess the incidence of late complications.

\section{Acknowledgments}

The authors are specially grateful to Dr. J. L. Zunzunegui, who shared his experience and knowledge with this center and enabled these first two cases of percutaneous pulmonary valve implantation to be carried out.

\section{Funding}

This research has not received any specific grant from agencies of the public, commercial, or non-profit sectors.

\section{Conflicts of interest}

The authors declare that they have no conflicts of interest.

\section{Ethical disclosures}

Protection of human and animal subjects. The authors declare that no experiments were performed on humans or animals for this investigation.
Confidentiality of data. The authors declare that they have followed the protocols of their work center on the publication of patient data.

Right to privacy and informed consent. The authors have obtained informed consent from the patients and/or subjects referred to in the article. This document is in the possession of the corresponding author.

\section{References}

1. Solana-Gracia R, Rueda F, Betrián $P$, Gutiérrez-Larraya F, Del Cerro MJ, Pan $\mathrm{M}$, et al. Pediatrics spanish registry of percutaneous melody pulmonary valve implantation in patients younger than 18 years. Rev Esp Cardiol (Engl Ed). 2018;71(4):283-90.

2. Ribeiro MS, Pedra CAC, Costa RN, Rossi RI, Manica JoL, Nascimento WTM, et al. Experiência inicial com o implante percutâneo da válvula Melody ${ }^{\circledR}$ no Brasil. Revista Brasileira de Cardiologia Invasiva. 2014;22:275-85.

3. Shimazaki $\mathrm{Y}$, Blackstone $\mathrm{EH}$, Kirklin JW. The natural history of isolated congenital pulmonary valve incompetence: surgical implications. Thorac Cardiovasc Surg. 1984;32(4):257-9

4. Rosengart TK, Feldman T, Borger MA, Vassiliades TA, Gillinov AM, Hoercher KJ, et al. Percutaneous and minimally invasive valve procedures: a scientific statement from the American Heart Association Council on Cardiovascular Surgery and Anesthesia, Council on Clinical Cardiology, Functional Genomics and Translational Biology Interdisciplinary Working Group, and Quality of Care and Outcomes Research Interdisciplinary Working Group. Circulation. 2008;117(13):1750-67.

5. Gillespie MJ, Rome JJ, Levi DS, Williams RJ, Rhodes JF, Cheatham JP, et al. Melody valve implant within failed bioprosthetic valves in the pulmonary position: a multicenter experience. Circ Cardiovasc Interv. 2012;5(6):862-70.

6. McElhinney DB, Hellenbrand WE, Zahn EM, Jones TK, Cheatham JP, Lock JE, et al. Short- and medium-term outcomes after transcatheter pulmonary valve placement in the expanded multicenter US melody valve trial. Circulation. 2010;122(5):507-16.

7. Armstrong AK, Balzer DT, Cabalka AK, Gray RG, Javois AJ, Moore JW, et al. One-year follow-up of the Melody transcatheter pulmonary valve multicenter post-approval study. JACC Cardiovasc Interv. 2014; 7(11):1254-62.

8. Cheatham JP, Hellenbrand WE, Zahn EM, Jones TK, Berman DP, Vincent JA, et al. Clinical and hemodynamic outcomes up to 7 years after transcatheter pulmonary valve replacement in the US melody valve investigational device exemption trial. Circulation. 2015;131(22):1960-70.

9. Torres AJ. Pre-stenting and Melody valve stent fracture: When more is less. JACC Cardiovasc Interv. 2017;10(17):1760-2

10. McElhinney DB, Cheatham JP, Jones TK, Lock JE, Vincent JA, Zahn EM, et al. Stent fracture, valve dysfunction, and right ventricular outflow tract reintervention after transcatheter pulmonary valve implantation: patient-related and procedural risk factors in the US Melody Valve Trial. Circ Cardiovasc Interv. 2011;4(6):602-14.

11. Frigiola A, Tsang V, Bull C, Coats L, Khambadkone S, Derrick G, et al. Biventricular response after pulmonary valve replacement for right ventricular outflow tract dysfunction: is age a predictor of outcome? Circulation. 2008;118(14 Suppl):S182-90.

12. Jones TK, Rome JJ, Armstrong AK, Berger F, Hellenbrand WE, Cabalka AK, et al. Transcatheter pulmonary valve replacement reduces tricuspid regurgitation in patients with right ventricular volume/pressure overload. J Am Coll Cardiol. 2016;68(14):1525-35.

13. Homann M, Haehnel JC, Mendler N, Paek SU, Holper K, Meisner H, et al. Reconstruction of the RVOT with valved biological conduits: 25 years experience with allografts and xenografts. Eur $\mathrm{J}$ Cardiothorac Surg. 2000;17(6):624-30.

14. Eicken A, Ewert $P$, Hager A, Peters B, Fratz S, Kuehne $T$, et al. Percutaneous pulmonary valve implantation: two-centre experience with more than 100 patients. Eur Heart J. 2011;32(10):1260-5.

15. Askovich B, Hawkins JA, Sower CT, Minich LL, Tani LY, Stoddard G, et al. Right ventricle-to-pulmonary artery conduit longevity: is it related to allograft size? Ann Thorac Surg. 2007;84(3):907-11; discussion 11-2.

16. Ansari MM, Cardoso R, Garcia D, Sandhu S, Horlick E, Brinster D, et al. Percutaneous pulmonary valve implantation: present status and evolving future. J Am Coll Cardiol. 2015;66(20):2246-55.

17. Wagner R, Daehnert I, Lurz P. Percutaneous pulmonary and tricuspid valve implantations: an update. World J Cardiol. 2015;7(4):167-77.

18. Boone RH, Webb JG, Horlick E, Benson L, Cao QL, Nadeem N, et al. Transcatheter pulmonary valve implantation using the Edwards SAPIEN transcatheter heart valve. Catheter Cardiovasc Interv. 2010;75(2):286-94. 
19. Haas NA, Moysich A, Neudorf U, Mortezaeian H, Abdel-Wahab M, Schneider $\mathrm{H}$, et al. Percutaneous implantation of the Edwards SAPIEN(TM) pulmonic valve: initial results in the first 22 patients. Clin Res Cardiol. 2013;102(2):119-28

20. Bergersen L, Benson LN, Gillespie MJ, Cheatham SL, Crean AM, Hor KN, et al. Harmony Feasibility Trial: acute and short-term outcomes with a self-expanding transcatheter pulmonary valve. JACC Cardiovasc Interv. 2017:10(17):1763-73.

21. Feltes TF, Bacha E, Beekman RH, Cheatham JP, Feinstein JA, Gomes AS, et al. Indications for cardiac catheterization and intervention in pediatric cardiac disease: a scientific statement from the American Heart Association. Circulation. 2011;123(22):2607-52.

22. Jalal Z, Galmiche L, Lebeaux D, Villemain O, Brugada G, Patel M, et al. Selective propensity of bovine jugular vein material to bacterial adhesions: an in-vitro study. Int J Cardiol. 2015;198:201-5.
23. Nguyen HH, Shahanavaz S, Van Hare GF, Balzer DT, Nicolas R, Avari Silva JN. Percutaneous pulmonary valve implantation alters electrophysiologic substrate. J Am Heart Assoc. 2016;5(10).

24. Lurz P Coats L, Khambadkone S, Nordmeyer J, Boudjemline Y, Schievano $\mathrm{S}$, et al. Percutaneous pulmonary valve implantation: impact of evolving technology and learning curve on clinical outcome. Circulation. 2008:117(15):1964-72.

25. Nordmeyer J, Khambadkone S, Coats L, Schievano S, Lurz P, Parenzan G, et al. Risk stratification, systematic classification, and anticipatory management strategies for stent fracture after percutaneous pulmonary valve implantation. Circulation. 2007:115(11):1392-7.

26. Secchi F, Resta EC, Cannaò PM, Tresoldi S, Butera G, Carminati M, et al. Four-year cardiac magnetic resonance (CMR) follow-up of patients treated with percutaneous pulmonary valve stent implantation. Eur Radiol. 2015;25(12):3606-13. 